\title{
Nonlinear Finite Element Analysis of the Ultimate Strength of Tube-Angle Combo Tower K-Joints*
}

\author{
Y. Z. Ju and D. H. Wang ${ }^{\mathrm{a}, \mathrm{b}, 1}$ \\ a School of Civil Engineering and Architecture, Northeast Dianli University, Jilin, China \\ ${ }^{\mathrm{b}}$ School of Civil Engineering, Harbin Institute of Technology, Harbin, China \\ ${ }^{1}$ hitwdh@126.com
}

УДК 539.4

\section{Нелинейный конечноэлементный расчет предела прочности К-образных соединений уголков и трубчатых элементов комбинированных башенных опор электропередач}

\author{
я. Ж. Жуа \\ а Факультет строительства и архитектуры, Северо-восточный электроэнергетический универ- \\ ситет, Цзилинь, Китай \\ ${ }^{\sigma}$ Факультет строительства, Харбинский политехнический университет, Харбин, Китай
}

Рассмотрено применение K-образных соединений уголков и трубчатых элементов в конструкичи комбинированных башенных опор электропередач. Построены конечноэлементные модели К-образных соединений, а предел их прочности рассчитан методом конечных элементов. Изучено влияние длины углового листа, толщины стального уголка и иирины его кромки на предел прочности комбинированных башенных опор электропередач. Полученные результаты свидетельствуют о том, что в определенном диапазоне предел прочности практически не изменяется с увеличением длины углового листа и возрастает с увеличением толщины стального уголка. Установлено, что изменение толщины кромки стального уголка незначительно влияет на предел прочности. Это исследование, а также полученные экспериментальные результаты создали основу для проектирования соединений уголков и трубчатых элементов комбинированных башенных опор электропередач.

Ключевые слова: К-образные соединения, комбинированная башенная опора, уголки и трубчатые элементы, предел прочности, конечноэлементный анализ.

Introduction. Continual improvement in the voltage levels of transmission lines and the height of transmission towers suggests that steel angles used in traditional steel single-angle transmission towers cannot meet safety design requirements, especially in the long-span transmission lines because of their particularly large span and height. Therefore, new transmission tower design methods were developed, e.g., the tube-angle combo tower. The diaphragm and oblique sections of tube-angle combo towers employ steel angles, with the tube component. A gusset plate connects the steel angle and tube. The joints shape a very complex configuration in a transmission tower, ensuring the structural safety of power transmission [1]. Domestic and foreign scientists have conducted extensive research regarding joint connections [2-5], but studies on the gusset plate of tube-angle combo towers are still relatively limited. Liu et al. [6] investigated the ultimate bearing capacity of

\footnotetext{
* Paper presented at the Third Global Annual Conference "Materials Science and Engineering" (CMSE2014, October 20-23, 2014, Shanghai, China).
} 
ribbed steel ring nodes. Ju et al. [7] studied the effect of the gusset plate thickness, tube diameter-to-thickness ratio, spacing between the steel angle area and steel tubes on the ultimate strength of steel angle-plate joints. However, there is scarce research on the gusset plate length and steel angle correlation parameter and the relationship between the steel angle-plate joint performance and angle parameter. The main objective of this study was to determine the effect of gusset plate length, steel angle thickness, and steel angle edge width parameters on the ultimate strength of K-joints.

\section{Model of Tube-Gusset Plate K-Joints.}

1.1. Geometric Parameters of Tube-Gusset Plate K-Joints. The main objective of this study was to determine the effect of the gusset plate length $L_{p}$, steel angle thickness $t$, and width $W_{j}$ on the ultimate strength of K-joints, with other geometric parameters remaining constant. The tube diameter $D$, tube length $L$, and gusset plate width $W_{p}$ were 159,950 , and $350 \mathrm{~mm}$, respectively, the inclination angle $\theta$, steel angle thickness $t$, and spacing $C$ made up $50^{\circ}, 15$ and $160 \mathrm{~mm}$, accordingly. The gusset plate thickness has a significant impact on the ultimate strength of tube-gusset plate joints [5], therefore, when analyzing the effect of each parameter on the joint, only the gusset plate thickness $t_{p}$ was changed to investigate the effect of geometric parameters on the ultimate strength of the tube-gusset plate joint. The geometric parameters of tube-angle combo tower joints are presented in Fig. 1.

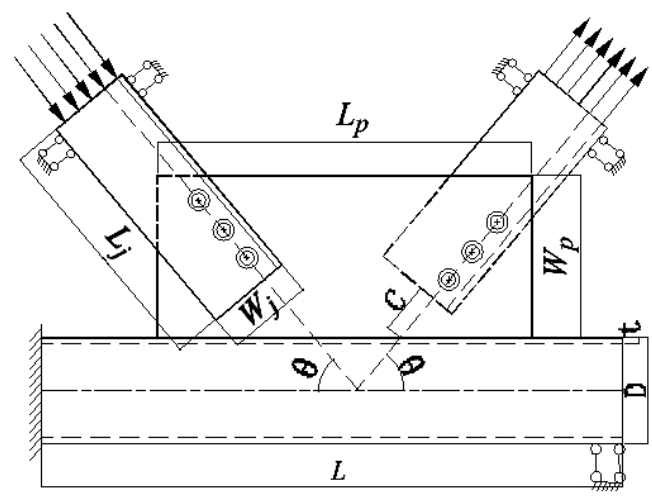

Fig. 1. Geometric parameters of tube-angle combo tower joints.

1.2. Finite Element Model of Tube-Gusset Plate K-Joints. A three-dimensional solid element description (SOLID45) was employed to simulate an 8-joint model. The method is suitable for solving nonlinear problems at large strains with a substantial displacement. With this the compression strength of the gusset plate at eccentric loads can be simulated [8]. The interaction surface contact elements CONTA174 and target unit TARGE170 were used to simulate the interaction between the gusset plate and steel angle.

The gusset plate and steel angle were made of Q235 steel. The yield strength of the material was $235 \mathrm{MPa}$ and Poisson's ratio was close or equal to 0.3.

Steel is considered to be an ideal material for elastic-plastic simulation (Fig. 2). To take account of the nonlinear mechanical properties of the gusset plate, the elastic-plastic behavior of steel was determined using the von Mises yield criterion and associated flow rule [9]. The von Mises or equivalent stress $\sigma_{e}$ is computed as

$$
\sigma_{e}=\left\{\frac{1}{2}\left[\left(\sigma_{1}-\sigma_{2}\right)^{2}+\left(\sigma_{2}-\sigma_{3}\right)^{2}+\left(\sigma_{3}-\sigma_{1}\right)^{2}\right]\right\}^{1 / 2}
$$

or 


$$
\sigma_{e}=\left\{\frac{1}{2}\left[\left(\sigma_{x}-\sigma_{y}\right)^{2}+\left(\sigma_{y}-\sigma_{z}\right)^{2}+\left(\sigma_{z}-\sigma_{x}\right)^{2}+6\left(\sigma_{x y}^{2}+\sigma_{y z}^{2}+\sigma_{z x}^{2}\right)\right]\right\}^{1 / 2} .
$$

Boundary conditions of the model were determined by referring to the overlap tubular joints [10]. One end of the steel tube was considered a fixed bearing, while the other one along the steel tube axis was assumed to be the displacement of the sliding carriage. Both ends of the steel angle were considered a sliding bearing whose displacement was only along the axis, with radial constraint. Boundary conditions are presented in Fig. 1. The method of grid partition is free mesh. The finite element model of the joint is shown in Fig. 3.

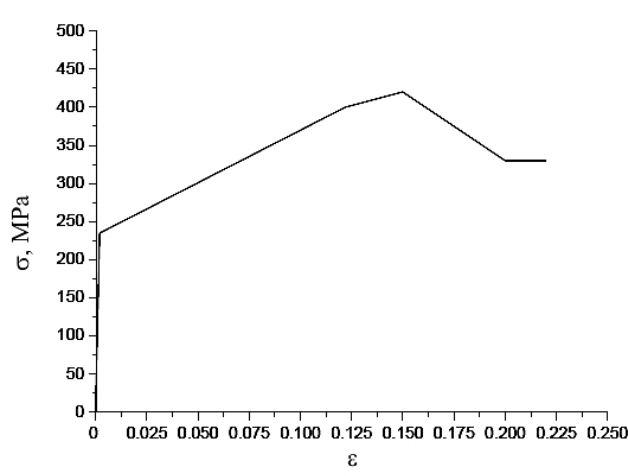

Fig. 2. Stress-strain relationships for steel.

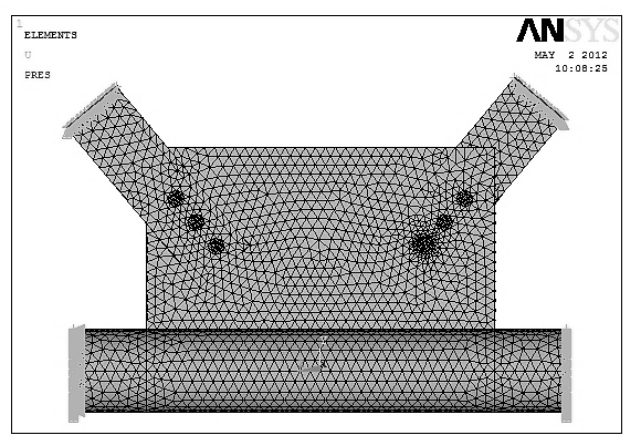

Fig. 3. Finite element model of tube-gusset plate K-joints.

\section{Effect of Different Parameters on the Ultimate Strength of Tube-Gusset Plate}

\section{K-Joints.}

2.1. Determination of the Ultimate Strength. The ultimate strength of gusset plate joints is defined as the maximum axial pressure that acts upon compressed steel angle ends with the failure of joints [11]. There are three criteria for the joint failure at static loads, used to determine the ultimate strength of gusset plate joints: ultimate strength criteria, ultimate displacement criteria, and visual crack extension. For the joint possessing a maximum load value on the load $P$-displacement $\delta$ curve, such as some compressed joints, the ultimate strength is defined as the maximum load (curve $A$ in Fig. 4). For a number of other joints whose loads continuously increase with strains, the ultimate strength is defined as the value corresponding to its maximum value (curve $B$ in Fig. 4). The ultimate strength of the joint equals to a smaller value between the ultimate strength defined by its criteria and the load value that corresponds to the maximum strain. The steel tube wall strain makes up $3 \%$ of the tube diameter as the ultimate displacement. When the plastic strain of the tube wall reaches this limit [5], the compression of the tube can lead to excessive plastic strain and joint failure.

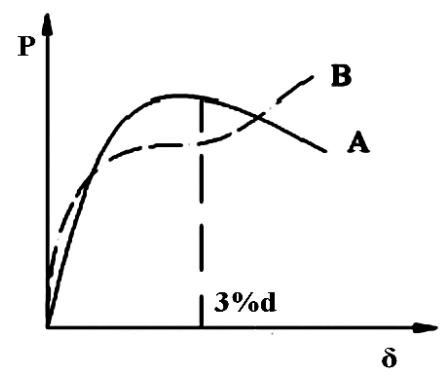

Fig. 4. Ultimate strength criteria. 
2.2. Effect of the Gusset Plate Length on the Ultimate Strength. The ultimate strength vs out-of-plane displacement for the tube-gusset plate joints with different gusset plate lengths is shown in Fig. 5. The ultimate strength changed slightly with an increase in the gusset plate length. The gusset plate lengths were 650, 690, 730, 770, and $810 \mathrm{~mm}$, with their thicknesses fixed. The maximum out-of-plane displacement was the same at different gusset plate lengths. The failure of tube-gusset plate joints corresponded to the gusset plate length, which led to the instability and ultimate failure of gusset plates.

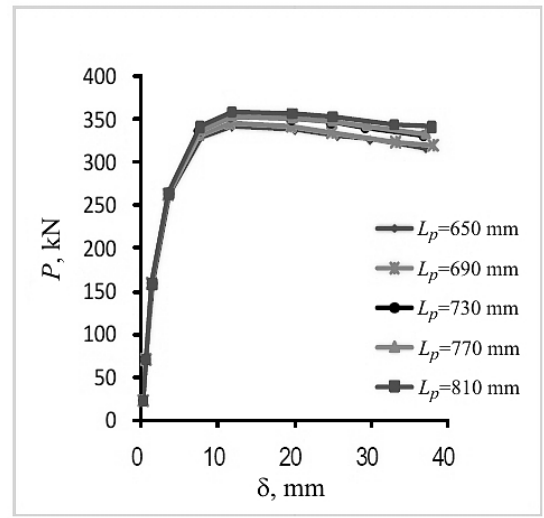

a

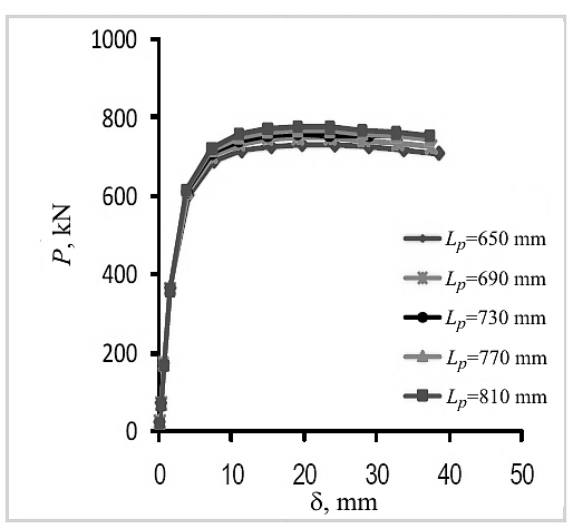

c

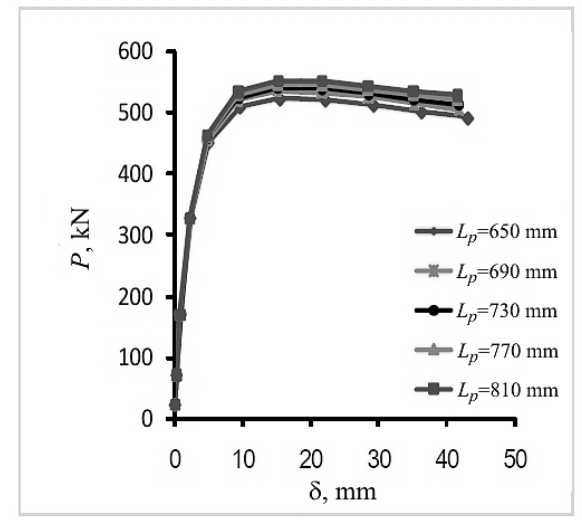

b

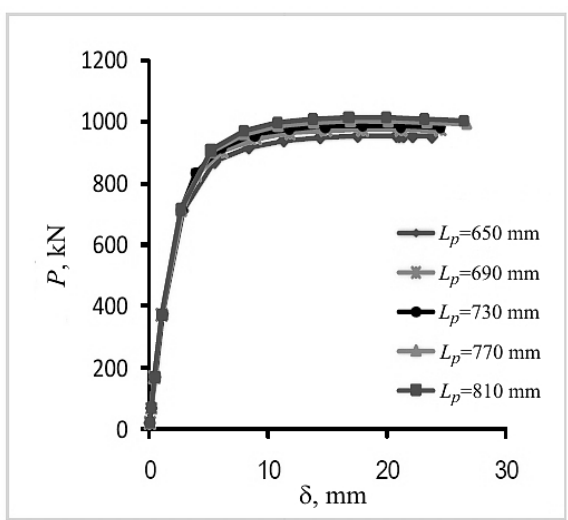

d

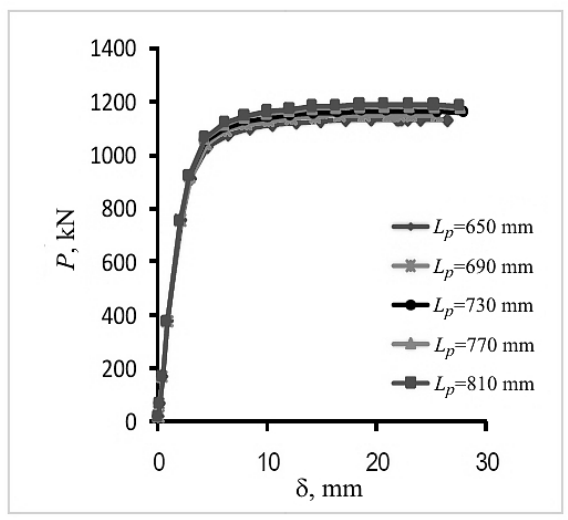

e

Fig. 5. Load-deflection curves for the joints with different gusset plate lengths. (Here and in Figs. 8 and 10: (a) $t_{p}=6 \mathrm{~mm}$; (b) $t_{p}=10 \mathrm{~mm}$; (c) $t_{p}=14 \mathrm{~mm}$; (d) $t_{p}=18 \mathrm{~mm}$; (e) $t_{p}=22 \mathrm{~mm}$.) 
The effect of the gusset plate length on the ultimate strength of $\mathrm{K}$-joints is shown in Fig. 6. It can be seen that the ultimate strength of tube-gusset plate joints remains the same. This is because the stresses in the zone of the gusset plate and main tube are minimal and portions under larger stresses were from the center to the sidewalls of the main tube. An increased length of the plate did not have any effect on the transfer of stresses. Therefore, the ultimate strength of the tube-gusset plates does not change. The failure mode of the gusset plate is shown in Fig. 7.

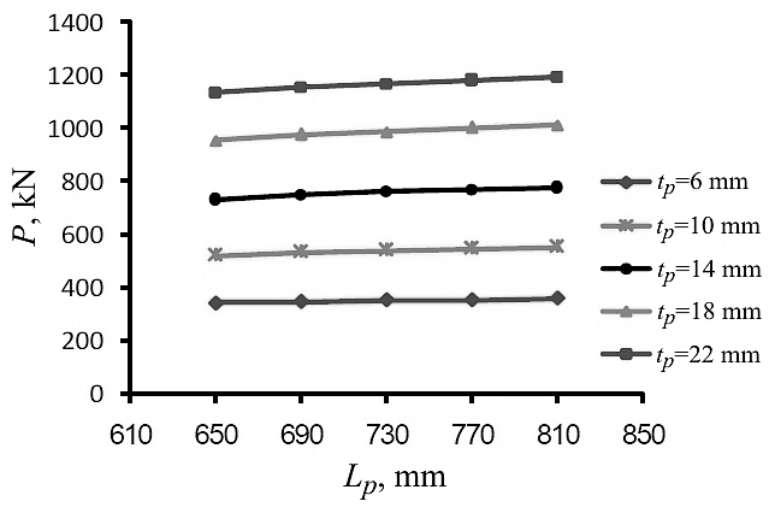

Fig. 6. Effect of the gusset plate length $L_{p}$ on the ultimate strength of the joints.

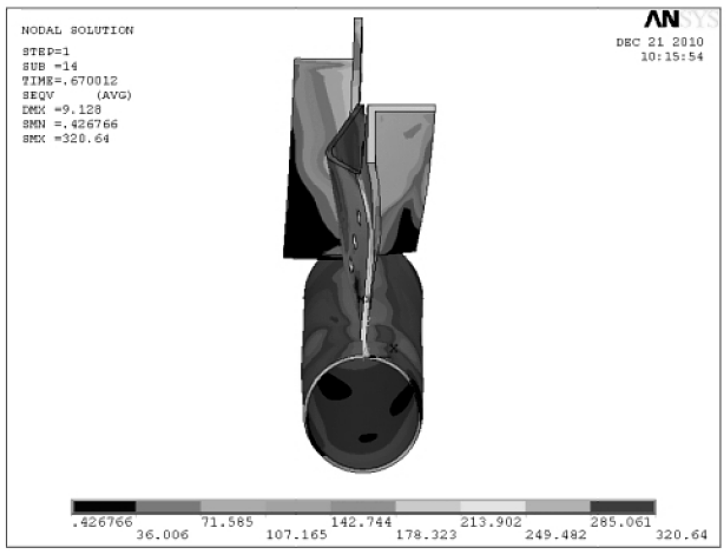

Fig. 7. Failure mode of the gusset plate.

2.3. Effect of the Steel Angle Thickness on the Ultimate Strength. The relationship between the ultimate strength and out-of-plane displacement of joints with different steel angle thicknesses is shown in Fig. 8. The ultimate strength is determined by the strength of the gusset plate. With an increase in the steel angle thickness, the ultimate strength continues growing. When the thickness of the gusset plate was 6 and $10 \mathrm{~mm}$, the maximum out-of-plane displacement of the plate remained practically the same. With the same failure mode and not very thick gusset plate, the failure of the joints first occurred at the latter. The results demonstrate that the maximum out-of-plane displacement is greatly different when the thickness of the gusset plate was larger than or equal to $14 \mathrm{~mm}$ (Fig. 8c-e). The maximum out-of-plane displacement of the joints was approximately $5 \mathrm{~mm}$ when the thickness of the steel angle was 6 or $10 \mathrm{~mm}$ (Fig. 8a, b). The failure of the joints was the result of local buckling of the steel angle, the effect of the gusset plate and main tube is insignificant. 


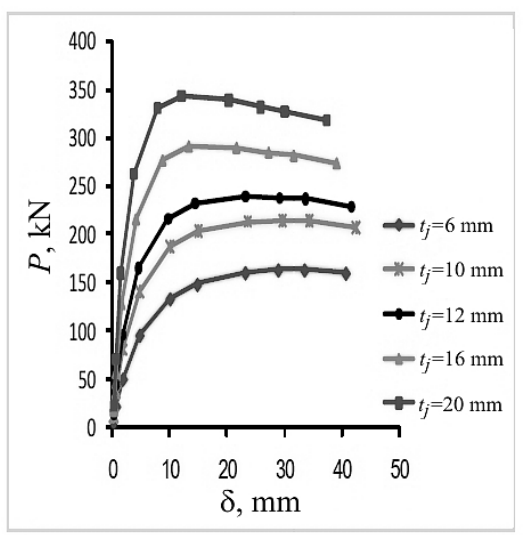

a

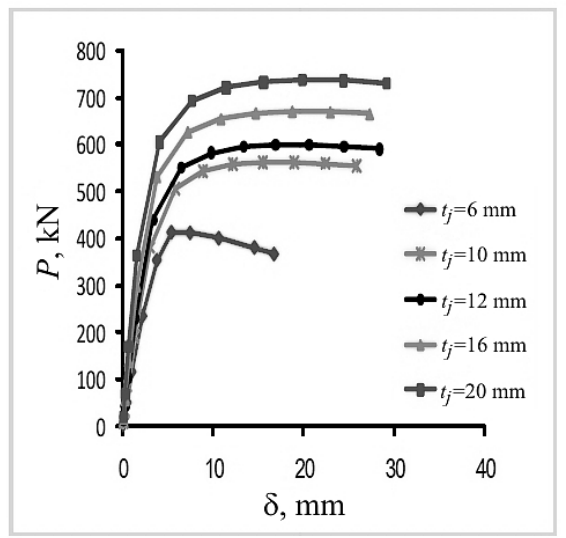

$\mathrm{c}$

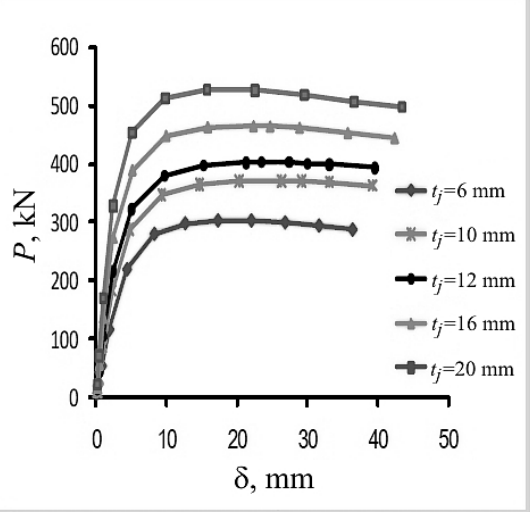

b

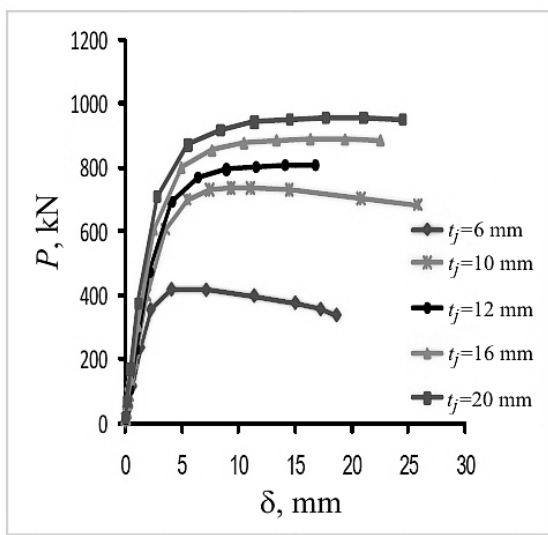

d

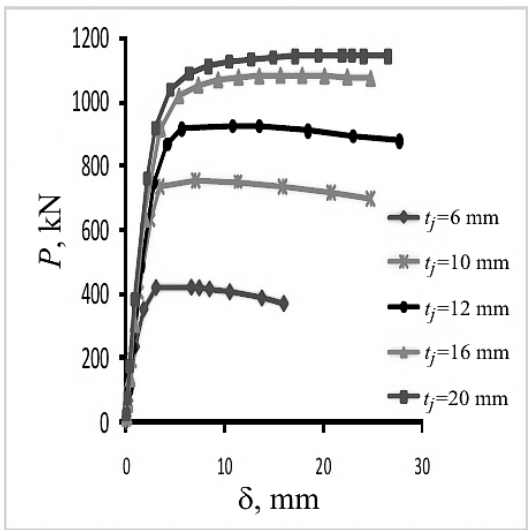

e

Fig. 8. Load-deflection curves for the joints with different steel angle thicknesses.

When the steel angle thickness was larger than $10 \mathrm{~mm}$, the maximum out-of-plane displacement of the joints was approximately $17 \mathrm{~mm}$, therefore, the failure mode was the result of the gusset plate failure.

The effect of the steel angle thickness on the ultimate strength of K-joints is shown in Fig. 9. It can be seen that the ultimate strength of the joints increases with the steel angle thickness. It may be attributed to the fact that the steel angle failure rate is inversely 


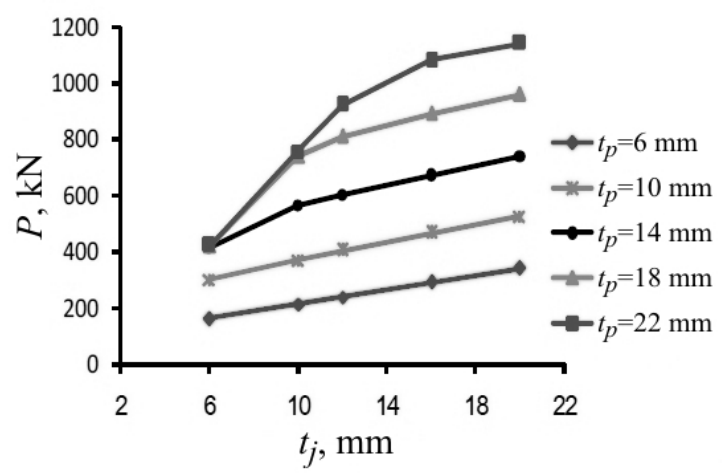

Fig. 9. Effect of the steel angle thickness on the ultimate strength of the joints.

proportional to the thickness and strength of the gusset plate and steel tube. When the gusset plate thicknesses were 6 and $10 \mathrm{~mm}$, the ultimate strength of the joints linearly increased with the steel angle thickness. With the gusset plate thickness of $14 \mathrm{~mm}$ and the steel angle thickness of $6 \mathrm{~mm}$, the steel angle buckling starts evolving. When the steel angle thickness was larger than $10 \mathrm{~mm}$, the ultimate strength of the gusset plate linearly increased along with the steel angle thickness, due to the gusset plate buckling in the joint. When the gusset plate thicknesses were 18 and $22 \mathrm{~mm}$, the steel angle thicknesses were 6 and $10 \mathrm{~mm}$, and the steel angle buckling in the joint was due to its low ultimate strength. When the steel angle thickness was larger than $10 \mathrm{~mm}$, the material was used more completely, and the ultimate strength of the joints was higher.

2.4. Effect of the Steel Angle Edge Width on the Ultimate Strength. The relationship between the ultimate strength and maximum out-of-plane displacement of the joints with different steel angle edge widths is shown in Fig. 10. It can be seen that with the gusset plate thicknesses of 6 and $10 \mathrm{~mm}$, the maximum out-of-plane displacements corresponding to the ultimate strength of the joint were similar. The failure modes of the joints were the same for the two cases, with their failure first occurring at the gusset plate. When the gusset plate thickness is $14 \mathrm{~mm}$ and steel angle edge width is $100 \mathrm{~mm}$, the failure mode of the joint was due to buckling of the steel angle. In this case, the maximum out-of-plane displacement was much smaller than that corresponding to other steel angle edge width values. With the gusset plate thickness of $18 \mathrm{~mm}$ and the steel angle edge width larger than $100 \mathrm{~mm}$, the failure mode of the joints was due to buckling of the steel angle. With the steel angle edge widths of 160 and $180 \mathrm{~mm}$, the failure of the joints first occurred at the gusset plate. The maximum out-of-plane displacement of the joint was larger than the failure occurring at the steel angle. With the gusset plate thickness of $22 \mathrm{~mm}$, the failure mode of the joints was due to buckling of the steel angle with its different edge widths. Therefore, the maximum out-of-plane displacement corresponding to the ultimate strength of the joints was relatively constant, approximately $12 \mathrm{~mm}$.

The relationship between the ultimate strength and steel angle edge width is shown in Fig. 11. With the gusset plate thicknesses of 6 and $10 \mathrm{~mm}$, the ultimate strength remained the same, thus, the steel angle edge width exerts little effect on the ultimate strength. With the gusset plate thickness of $14 \mathrm{~mm}$ and steel angle edge width of $100 \mathrm{~mm}$, the ultimate strength of the joints increased slightly. This is because the failure modes changed. The strength resource of the gusset plate was completely exhausted, with buckling of the gusset plate occurring in the joints. Therefore, the ultimate strength increased slightly. However, the ultimate strength remained the same when the steel angle edge width increased, demonstrating its little effect on the ultimate strength. With the gusset plate thickness of $18 \mathrm{~mm}$, the failure mode changed from steel angle failure to that of the gusset 


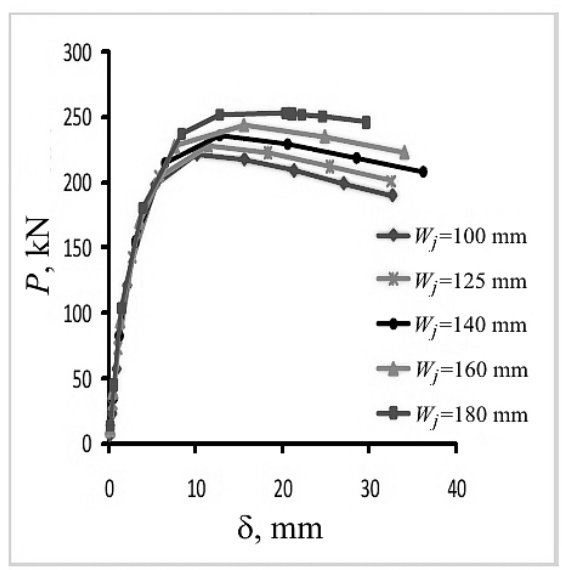

a

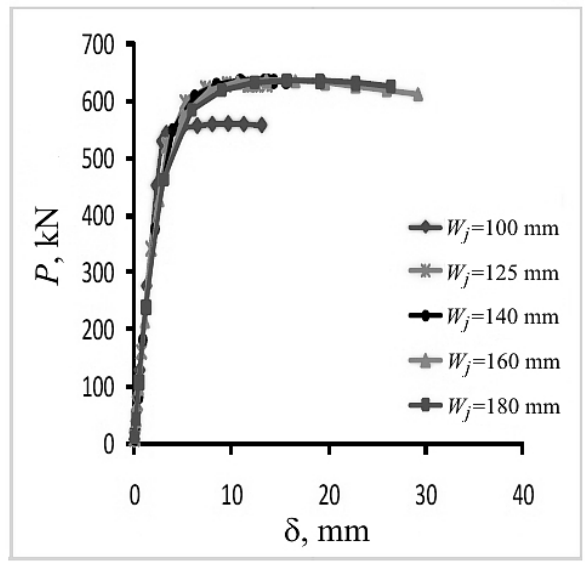

c

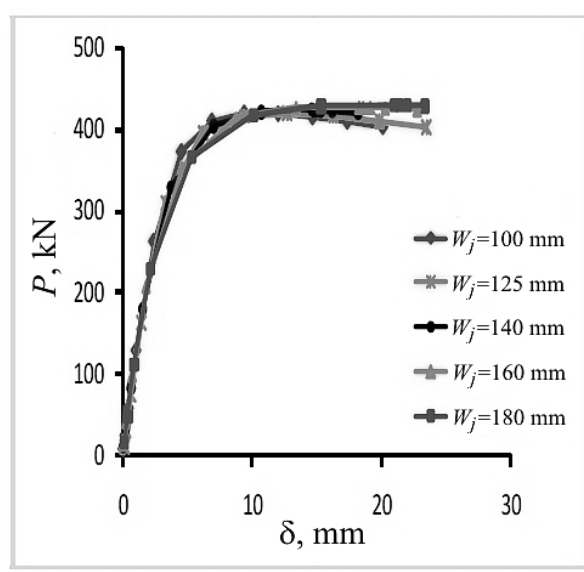

b

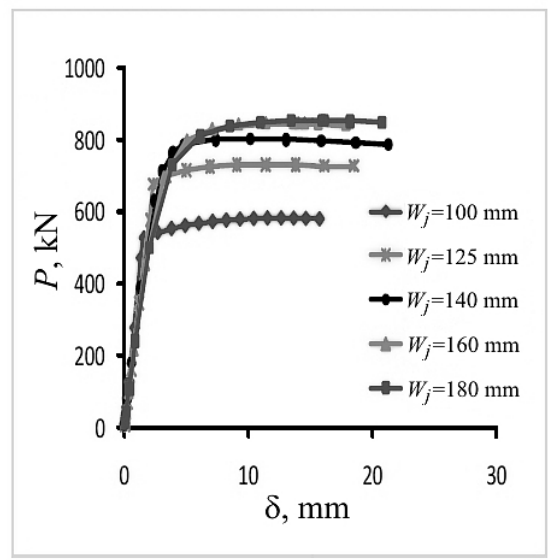

d

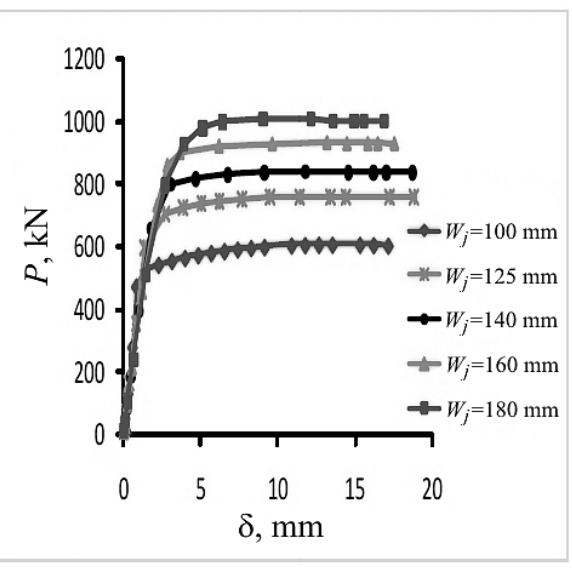

e

Fig. 10. Load-deflection curves for the joints with different steel angle edge widths.

plate, so the ultimate strength increased. In fact, this case is unusual for practical engineering because most failure of the joints is due to buckling of the gusset plate [10]. Hence, the steel angle edge width had little effect on the ultimate strength of the joints. 


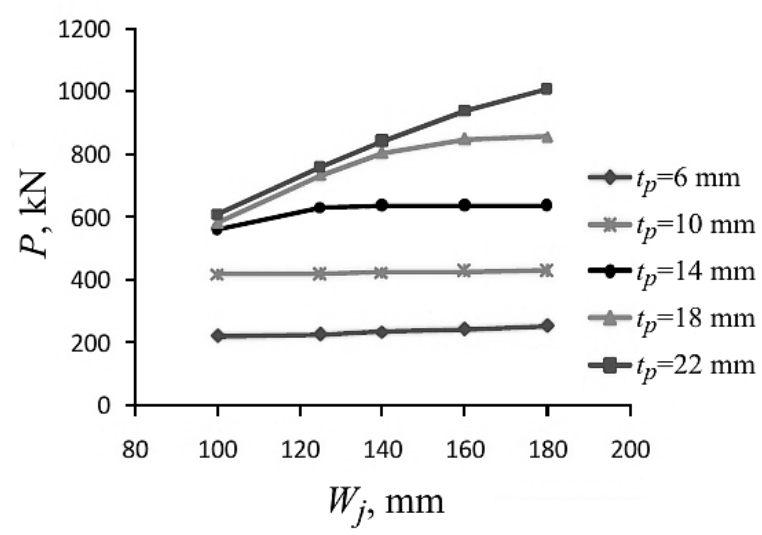

Fig. 11. Effect of the steel angle edge width on the ultimate strength of the joints.

Conclusions. The gusset plate width was the most important factor affecting the ultimate strength of tube-angle combo tower joints, with the minimum effect of the gusset plate length. The ultimate strength of the joints remained unchanged when the gusset plate length varied from 650 to $810 \mathrm{~mm}$, therefore, this parameter cannot be a major factor for the engineering design.

With the steel angle thicknesses of 6 and $10 \mathrm{~mm}$, failure of the joints was usually caused by buckling of the steel angle, and with the steel angle thickness larger than $10 \mathrm{~mm}$, the failure mode of the joints was due to failure of the gusset plate, causing the ultimate strength of the joint to increase. Therefore, it is suggested to incorporate steel angle joints with a thickness larger than $10 \mathrm{~mm}$ in the engineering design.

The ultimate strength of the joints did not exhibit any obvious change, with the steel angle edge width varying from 100 to $180 \mathrm{~mm}$. For the joint design, a small steel angle edge width should be chosen.

Supported by National Natural Science Foundation of China (No. 50878040).

\section{Резюме}

Розглянуто використання К-подібних з'єднань кутиків і трубчастих елементів у конструкції комбінованих баштових опор електропередач. Побудовано скінченноелементні моделі К-подібних з'єднань, а границю їх міцності розраховано методом скінченних елементів. Вивчено вплив довжини кутового листа, товщини стального кутика і ширини його кромки на границю міцності комбінованих баштових опор електропередач. Отримані результати свідчать про те, що у визначеному діапазоні границя міцності практично не змінюється 3 ростом довжини кутового листа i збільшується з ростом товщини стального кутика. Установлено, що зміна товщини кромки стального кутика несуттєво впливає на границю міцності. Це дослідження та отримані експериментальні дані послужили основою для проектування з'єднань кутиків і трубчастих елементів комбінованих баштових опор електропередач.

1. Y. Ding, "Discussion on some design problems in circular tubular joints," Spatial Struct., 2, No. 8, 56-64 (2002).

2. S. Willibald, Bolted Connections for Rectangular Hollow Sections under Tensile Loading, Doctoral Dissertation (Eng.), University of Karlsruhe (2003).

3. E. M. Dexter and M. M. K. Lee, " Static strength of axially loaded tubular K-joints. I: Behavior,” J. Struct. Eng., 125, No. 2, 194-201 (1999). 
4. E. M. Dexter and M. M. K. Lee, "Static strength of axially loaded tubular K-joints. II: Ultimate capacity,” J. Struct. Eng., 125, No. 2, 202-210 (1999).

5. X. Shu, Y. Xiao, and Z. Yuan, "Nonlinear finite element analysis on ultimate strength of tube-gusset K-joints," J. Build. Struct., 40, No. 5, 92-96 (2010).

6. H. Liu, Z. Li, and M. Li, "Study of ultimate strength of steel tubular joint with annular ribbed plate of transmission towers," Eng. Mech., 27, No. 10, 65-73 (2010).

7. Y. Z. Ju, Q. Cao, and J. F. Lei, "A study of ultimate bearing capacity of combo steel tube tower joints," East China Electric Power, 39, No. 2, 213-216 (2011).

8. G. Lou, G. Li, and Q. Lei, "Recent developments in the behavior and design of highstrength bolted endplate connections," Progress in Steel Building Structures, 8, No. 2, 8-21 (2006).

9. ANSYS Mechanical APDL Theory Reference, ANSYS Inc., PA, USA (2012).

10. F. Gazzola, M. M. K. Lee, and E. M. Dexter, "Design equation for overlap tubular K-joints under axial loading," J. Struct. Eng., 126, No. 7, 798-808 (2000).

11. Y. Z. Ju and J. F. Lei, "Analysis on gusset plate failure mode of tube-angle combo tower," East China Electric Power, 39, No. 8, 1238-1243 (2011).

Received 20. 10. 2014 